\title{
The formation of state capitalism models in the oil industry: Russia and the world
}

\author{
Dmitry Rodnyansky ${ }^{1, *}$, Ivan Makarov ${ }^{2,4}$, Olga Mitrofanova $^{3}$, Yuliya Sukhina ${ }^{4}$, and Anna \\ Kisova $^{3}$ \\ ${ }^{1}$ Kazan federal university, Kazan, Russia \\ ${ }^{2}$ Financial University under the Government of the Russian Federation, Lipetsk branch, Lipetsk, Russia \\ ${ }^{3}$ Lipetsk state technical university, Lipetsk, Russia \\ ${ }^{4}$ The Russian presidential academy of national economy and public administration, Lipetsk, Russia
}

\begin{abstract}
In modern conditions, issues related to the effectiveness of the regulation of the oil industry by the state are becoming increasingly important. In January 2018, the World Economic Forum was held in Davos, at which, in particular, the impact of the growth of protectionist trends in the global trade in hydrocarbons and the impact of climate change on the planet on the export of hydrocarbons was noted. As a result of the forum, the key ways of adjusting the policy of states in the relevant area were identified. At the same time, a significant number of states are already seeing the process of changing state regulation of the industry. Given the current crisis situation associated with the coronavirus pandemic, an increasing number of private enterprises are coming under state control, which gives rise to new discussions about the renaissance of the so-called state capitalism.. In this article, the authors examined country specific features, as well as various concepts of the formation and development of state capitalism in the oil industry.
\end{abstract}

\section{Introduction}

To characterize the state of the oil industry, as well as to forecast its development, such indicators as the level of production, reserves, the depth and volume of energy processing, as well as export / import indicators are used. At present, the oil industry is still the area on the development of which the revenue base of the federal budget largely depends. In the postcrisis period 2015-2016. there was a slight change in the ratio of the share of oil and gas budget revenues in comparison with other sources, but this was largely due to a decrease in world prices for oil and oil products. Already in 2017, the share of receipts from the export of raw materials increased by $32 \%$ and amounted to $40 \%$ of all budget revenues.

In accordance with the report of the Ministry of Finance of the Russian Federation in 2019 , oil and gas budget revenues amounted to 7.92 trillion rubles, which is $28 \%$ of all budget revenues. At the same time, the methodology of the Ministry of Finance of the Russian Federation takes into account only the income from the mineral extraction tax, export customs duties and tax on additional income. At the same time, the tax on profit of oil and

* Corresponding author: drodnyansky@gmail.com 
gas companies, VAT from similar business structures and a number of other tax and non-tax receipts are not taken into account in these statistics. According to RBC experts, the share of these "expanded" oil and gas revenues in 2018 could reach up to 1.5 trillion. rubles, which is $17 \%$ higher than the estimates of the Ministry of Finance. And if we refer to the oil and gas revenues paid dividends, revenues from exports of companies with state participation and other payments, then the share of these revenues will approach $50 \%$ of total revenues.

The discussion about the effectiveness of state participation in strategic sectors of national economies has been going on for many years.

Exploring the specifics of the regulation of raw material industries by the state, it seems possible to point out the existence of the following models of state policy in the energy sector $[1,2,3]$.

1. In states in which energy resources are abundant, the model of national monopoly prevails. The specifics of this model are as follows. The energy industry acts as a locomotive for the development of the country's economy. The state regards energy as a sphere, regulation and control in respect of which is completely the prerogative of the state. In this regard, there are tangible restrictions on entry into the industry for non-state players (both domestic and foreign).

2. Model of national competition. The formation of this model began in the eighties nineties of the last century. This period was characterized by energy reforms in countries such as New Zealand, the United States of America, and a number of Western European countries.

Prior to this period, energy was a sphere of state dominance. In the eighties, with the spread of liberal approaches, there was a decrease in state participation in various sectors of the economy. As a result of such reforms, significant positive dynamics was observed in the economy in the short term. At the same time, over a longer period, the implementation of the liberal strategy resulted in the development of crises in the energy sector. In the energy sector, it was necessary to implement large projects, but it turned out to be difficult to attract investments in them. The consequence was a tangible shortage of energy resources, which, in turn, led to an increase in prices for these resources. Possible directions for solving this issue, tested in practice, are presented in the following form. In Chile, the United States of America, Argentina, government intervention in the energy sector has increased, accompanied by a reduction in competition in the industry. In a number of other countries, general laws and standards for energy policy have been developed, which have acquired an integral character. On this basis, in a number of Scandinavian countries (Sweden, Norway, Finland, Denmark), a model of integration competition was formed, focused on the implementation of a single policy in the energy sector, the creation of a single energy market. There is significant government participation in these countries. At the same time, the role of coercive management and the use of administrative influences is comparatively smaller, with the predominance of creating conditions for market relations (in particular, through the development of regulatory frameworks for relevant relations).

It seems necessary to characterize the approaches of various states to the implementation of energy policy, the corresponding mechanisms of state participation in regulation with an assessment of the effectiveness of the functioning of the corresponding mechanisms $[4,5]$.

\section{Methods}

For a long time, science has been exploring public property along with private, analyzing the relationship in which they exist and efficiency. This issue has acquired relevance in Russia at the post-privatization stage; world research on this topic has been carried out since the $80 \mathrm{~s}$ of the twentieth century. Research in this area is based on the works of D. Sappington and J. Stiglitz, which characterize the changes brought about by the privatization process. In 
addition, the works of A. Shleifer and R. Vishnu are also basic, where a completely different point of view is considered, which is expressed in the influence of social and political factors on the state share in the economy. Megginson's theory concludes that at the turn of the XXXXI centuries, state participation in the economy is declining. This is becoming a worldwide trend, with some exceptions $[6,7,8,9]$.

\section{Results and discussion}

The problem of returning to some extent "state capitalism" is today ambiguous: large national companies are actively supported, control over state assets is increasing, powerful financial flows are attracted through agents controlled by the government. The opposite trend emphasizes that due to the super profits received from the sale of energy resources in the period 2005-2014, the sovereign funds of export-oriented states are strengthening. The development of the Chinese economy, which on a global scale has become advanced, is noted, obtaining competitive advantages through government regulation measures in China and Singapore. It stands out that since 2011, the foreign policy pursued by Western countries has become more and more militarized.

"State capitalism" and its development were influenced by the global crisis of 2008-2009. To mitigate its consequences, many states had to turn to a special regulation measure: private assets in sectors of the economy of strategic importance were nationalized. The studies carried out state the fact that state participation in the Russian economy has increased from $39.6 \%$, characteristic of 2006 , to $46 \%$ of GDP, achieved in 2016 . Over these 10 years, the contribution to GDP of companies with state participation increased by $1 / 5$ and increased to $25.3 \%$, the public administration sector is $19.2 \%$ of GDP. It is important to note that employment in companies with state participation also tends to grow. The government contribution rate is about $10 \%$ higher than in other developing countries. Such positive dynamics are evidence of alarming trends in the Russian economy.

Since 2009, many states have started to implement privatization measures. Most of the income from them, namely 58.7\%, was received in the period 2015-2016; in total, over the past 4 years, these incomes amount to about $\$ 998.8$ million. This mechanism is used for different purposes, which depend on the policies pursued by a particular country. This can be both earning additional income and strategic goals, in particular, the growth of economic efficiency.

Since 2010, the share of state participation in the Russian economy has been growing with the help of a mechanism that increases the role of state structures in the processes of distributing finance. Moreover, state structures are strongly supporting vertically integrated companies. At the same time, quantitative changes are also observed: the packages of state shares of the largest companies that are significant for the country are expanding. These trends are distinguished by certain shortcomings, the most significant of which is that the rates and directions of economic growth in Russia are slowing down. Weak economic growth is due to the fact that market regulation is replaced by administrative one, as a result of which domestic production suffers the so-called "technological famine". However, in world practice, there are more examples when state-owned companies are competitive and show high efficiency in their activities.

The next point related to the share of the state in the economic activities of companies is the blurred boundaries of the very definition of the public sector and the inaccuracy of the criteria by which a company belongs to SOE (State owned enterprises). Today, there are two areas of state participation in the process of creating added value. This is the functioning of SOE at any stage and the provision of state. services that are based on budget funding. Difficulties are raised by certain questions: how to evaluate the performance of such companies, how to organize statistical accounting in SOE, which does not exist now. There 
is also no methodology by which the share of SOE in the state GDP is calculated. All this taken together allows us to conclude that the assessment of the state contribution to GDP is ambiguous and uncertain.

But in the world, most countries have the same problems. The concept of SOE, as well as the assessment methodology, is today unified by the OECD, which defines the company with the state. participation as a legal entity, in relation to which the state exercises the right of ownership through control. Thus, the authorized capital of the company by $10-100 \%$ should fall to the share of the state (majority / minority shareholdings). The rules and principles of information disclosure in Russia allow both direct participation of the state as the owner of shares, and indirect. Through a chain of organizations.

The Federal State Statistical Service of Russia provides certain statistics characterizing the distribution of capital participation in enterprises of mixed ownership. According to these data, the border of state participation in the authorized capital of the company has been reduced to $0 \%$, which causes ambiguity in the assessment methodology. The state contribution to the economy loses its clear definition.

According to the data presented in the study by A. Abramov, I. Aksyonov, A. Radygin and M. Chernovaya, Russia is among the top five countries with the maximum share of companies with state participation both in terms of the number of people employed in them and in terms of market capitalization. or the value of companies. (table 1)[10].

Table 1. Top-5 countries by the share of companies with state participation in the economy 2016.

\begin{tabular}{|c|c|c|c|c|c|c|c|}
\hline Country & \multirow{2}{*}{$\begin{array}{c}\text { Quantity } \\
\text { of SOE }\end{array}$} & \multicolumn{2}{|c|}{ Market cap, billion dollars } & \multicolumn{3}{|c|}{ Employed } \\
\cline { 3 - 8 } & & SOE & $\begin{array}{c}\text { Market } \\
\text { cap }\end{array}$ & $\begin{array}{c}\text { Share } \\
\text { of SOE }\end{array}$ & SOE & $\begin{array}{c}\text { Total in } \\
\text { country }\end{array}$ & $\begin{array}{c}\text { Share } \\
\text { of SOE }\end{array}$ \\
\hline China & 51341 & 29201 & 8188 & 356,6 & 20248999 & 657253800 & 3,1 \\
\hline Greece & 42 & 83 & 42 & 198,2 & 42927 & 2341300 & 1,8 \\
\hline Slovenia & 37 & 13 & 6 & 207,1 & 47052 & 762100 & 6,2 \\
\hline Norway & 55 & 108 & 194 & 55,6 & 230601 & 2460500 & 9,4 \\
\hline Russia & 105 & 175 & 473,7 & 36,9 & 3671564 & 68495000 & 5,4 \\
\hline
\end{tabular}

Thus, we can see that Russia is ahead of most developed and developing countries in terms of the share of companies with state participation. The exceptions are China and Norway, they are characterized by "state capitalism" of a special kind. The policies of these countries are subject to detailed review.

\section{Conclusion}

In China, companies with state. participation - the main subjects that ensure the stable growth of the economy, and the main elements, the economic system of which is being reformed. Record rates of economic growth have been evident since 1978. Researchers for the most part associate this with the property of settlement and volost enterprises: they belong to the municipal authorities. The drivers of China's economic growth were neither market regulation, nor private property, nor decentralization. This fact is confirmed by the Fortune Global 500 ranking, in which Chinese companies occupied 98 positions in 2015, 77.5\% of which are state-owned companies. The explanation for this was the presence of political attitudes that became an obstacle to the functioning of the market principles of the economy. The only way out and the economic way was the development of entrepreneurial activity in the conditions of incomplete privatization of enterprises and organizations that belonged to the state, in order to preserve and develop state-owned enterprises.

Huang Yashen in his research book "Capitalism in Chinese. Government and Business "writes that the main economic growth in China took place in the 80s of the XX century in rural settlements, but in a sector in which production was not associated with agriculture [11]. 
This reform was completed already in the 90s. Chinese enterprises of settlement and volost significance are organizations and enterprises that operate in rural areas, while the organizational and legal form can be any. The next decade is characterized by the fact that the main investment flows were already directed to urban settlements, and rural enterprises began to receive much less funding. Since 1990, the number of civil servants has grown significantly.

These government decisions reinforced state capitalism as a weighted average between corrupt, state-controlled urban areas and competitive, entrepreneurial townships. It is important to note the consequence of the reforms undertaken in China, consisting in the absence of strong GDP growth in the period 1980-1990 and the presence of cardinal, significant changes in the socio-economic life of citizens. Today, there are three oil companies in China, which are formally independent, but their leadership and functioning are determined by government agencies.

The situation in the oil sector in Norway is different. Historically, the emphasis here has been on government regulation. According to a study conducted by the Organization for Economic Development and Cooperation, Norway ranks third in the world in terms of the share of the public sector in the economic life of the country (\$131 billion). It is the only European country to exceed the 20 percent threshold of the weighted average, which is calculated for the top ten largest government. of enterprises and together with revenues takes into account market capitalization and net income. In Norway it is $48 \%$, in Russia, for comparison, $81 \%$.

The largest Norwegian company, oil and gas Statoil, is $100 \%$ state-owned. But the level of government participation in the Norwegian economy was high even before the oil and gas boom. Today, 1/5 of government revenue comes from Statoil. Thanks to the development of the oil and gas sector, which is in the hands of the state, a significant sovereign fund has been created - a guarantee of future generations, providing citizens with a decent standard of living. In 1963, the state made an important decision and secured the right to natural resources at the legislative level. With subsequent decisions, the level of state participation was extended to the processing industry.

The study of the experience of countries that use state regulation as a tool for conducting state policy shows that even with such an approach, as it were, far from the market, many states have secured a leading position in the world arena: the GDP of these countries is growing at a high rate, and the quality of life of citizens is at a decent level.

\section{References}

1. S. Clo, C.V. Fiorio, M. Florio, European Journal of political economy, 1 (2016)

2. S. Estrin, Z. Liang, D. Shapiro, M. Carney, Acta Oeconomica 69, 1, 175 (2019)

3. I. Alami, A. Dixon, State capitalism(s) redux? Theories, tensions, controversies. Competition \& Change, 1 (2019)

4. G.A. Karolyi, R.C. Liano, Journal of corporate finance 6, 1 (2013)

5. A. Musacchio, S.G. Lazzarini, R.V. Aguilera, New Varieties of State Capitalism: Strategic and Governance Implications. Academy of Management Perspectives, 1 (2013)

6. W.L. Megginson, B. Ullah, Z. Wei, J. of Banking \& Finance, 276 (2014)

7. E. L. Glaeser, A. Shleifer, J. of Economic Literature XLI, 401 (2003)

8. N.W. Leung, M.-A. Cheng, China J. of Accounting Research, 1 (2013)

9. D. Palcic, E. Reeves, Public Organization Review, 117 (2013)

10. A. Abramov, A. Radygin, M. Chernova, Economic Issues 12, 61 (2016)

11. X. Huang, Asian Pacific Economic Literature 6, 1 (2018) 